кандидат социологических наук, доцент кафедры социологии

Астраханского государственного университета

\section{ДОСУГОВЫЕ ПРЕДПОЧТЕНИЯ СОВРЕМЕННОЙ РОССИЙСКОЙ МОЛОДЕЖИ: СРАВНИТЕЛЬНЫЙ СОЦИОЛОГИЧЕСКИЙ АНАЛИЗ}

\section{Аннотация:}

В статье рассматривается досуг современной молодежи, который является одной из основополагающих сфер ее жизнедеятельности. Трансформация всех сторон жизни российского общества приводит к изменению социокультурной ситуации в области досуга. Сравнительный социологический анализ исследований досуга позволил выявить определенные закономерности и региональные особенности досуговых предпочтений молодежи. Например, в Астраханской области молодое поколение предпочитает пассивный досуг (Интернет, прослушивание музыки, просмотр телевизора, чтение), несмотря на то что понизовье Волаи славится рыбалкой и охотой. В Московской области и Республике Бурятия в приоритете активный досуе: 59,3 \% молодых москвичей занимаются спортом; в Бурятии молодых людей привлекают паркур, альпинизм, охота и m. п. Региональные особенности молодежного досуга определяются социально-демографическими характеристиками, процессами, происходящими в обществе, состоянием здоровья, условиями окружающей среды и m. д. Однако следует отметить, что культура досуговой деятельности является непосредственно результатом жизнедеятельности самой личности, ее стремления самовыразиться и в то же время успешно социализироваться в современном обществе: превратить досуг в средство приобретения не только новых увлечений, но и знаний, умений, способностей. Примечательно, что основные проблемы организации досуга во многом схожи в разных городах России: материальная доступность и высокая стоимость досуговых услуг зачастую сопровождаются низким качеством и недостаточным разнообразием.

\section{Ключевые слова:}

активный и пассивный досуа, молодежь, свободное время, субъективная оценка, доход, досуговые услуги.
$\mathrm{PhD}$ in Social Science, Associate Professor, Sociology Department, Astrakhan State University

\section{LEISURE PREFERENCES OF THE MODERN RUSSIAN YOUTH: A COMPARATIVE SOCIOLOGICAL ANALYSIS}

The paper deals with the leisure of the modern young people, which is one of the fundamental areas of their life. All aspects of the life of Russian society are transformed, and it leads to the social and cultural changes in leisure activities. A comparative sociological analysis of leisure studies revealed certain regularities and regional features of the youths' leisure pursuits. For example, in Astrakhan region, the younger generation prefers being indulged in passive leisure (doing something on the Internet, listening to music, watching TV, reading) despite the fact that the Volga lowlands are famous for fishing and hunting. In Moscow region and the Republic of Buryatia, active leisure is the priority. Thus, $59.3 \%$ of young citizens in Moscow are engaged in sports, the Buryat youth is fond of parkour, mountaineering, hunting. The regional features of the youth leisure are determined by the social and demographic characteristics, social processes, health, environment. However, it should be noted that the culture of leisure is the result of activities of a person, his desire to express himself, socialize with a contemporary society, i.e. to transform leisure into a way of finding a new hobby and acquiring knowledge, skills, and abilities. It is noteworthy that the main problems of leisure-time activities are very similar in different cities of Russia. The availability and the high cost of leisure services provided are often accompanied by their low quality and the lack of their diversity.
Keywords: active and passive leisure, youth, leisure time, subjective assessment, income, leisure services.

Современное общество генерирует все новые фрормы организации свободного времени. Сегодня человек испытывает постоянную потребность в самообразовании и саморазвитии, развлечении и психологической релаксации, социальном общении, выходящем за рамки рабочего времени. В условиях динамичного развития социума свободное время для индивида является подлинной ценностью. Научное сообщество проявило интерес к исследованию данного феномена в конце XIX - начале XX в. В частности, К. Маркс определяет свободное время (свободное для удовольствий, досуга) как форму общественного богатства [1, с. 264]. М. Каплан разрабатывает гуманистическую модель, в которой досуг выступает центральным элементом культуры [2]. С.Н. Иконникова рассматривает свободное время как самодостаточную структурную часть бюджета времени и приравнивает его к понятию «досуг» [3, с. 20]. Соотнося слово «досуг» с древнеславянским «досягать», «досягнуть», Е.И. Дробинская утверждает, что «досуг» буквально означает возможность что-то совершить, т. е. это деятельность, посредством которой человек восстанавливает способность к труду и самосовершенствованию [4, с. 7-8]. 
Являясь частью свободного времени, досуг привлекает молодежь добровольностью выбора его различных форм, демократичностью, эмоциональной окрашенностью, возможностью сочетать фризическую, интеллектуальную и творческую деятельность [5, с. 336]. В связи этим весьма актуально изучение досуговых предпочтений молодых людей эпохи потребления, проживающих в разных субъектах Российской Федерации. Для сравнительного социологического анализа выбраны следующие регионы: город Москва (2013 г., n = 480), Республика Бурятия (2013 г., n = 625), Астраханская (2014 г., n = 594), Мурманская (2013 г., n = 683) и Оренбургская (2011 г., $\mathrm{n}=690$ ) области. Данный выбор определен разноплановым подходом к организации мероприятий в досуговой сфере, который позволяет учитывать социогрупповые особенности потребителей рассматриваемых услуг и региональную специфику (как географическую, климатическую, так и экономическую, социальную, этническую и др.).

Досуг реализует преимущественно рекреационную функцию, функцию восстановления сил и отдыха, развлечения и общения, значит, его главной целью выступает деятельность, направленная на всестороннее развитие человека. Отсюда следует вопрос: «Хватает ли Вам свободного времени на то, чтобы посвятить его досугу?». Астраханская молодежь отвечает на него следующим образом: да, хватает (33,5 \%); на что-то хватает, на что-то нет $(47,5)$; вообще нет свободного времени, чтобы посвятить его досугу (19,0 \%). Примечательно, что на выбор ответа влияет возрастной фрактор: чем младше респондент, тем меньше он ощущает дефицит времени для досуговых увлечений (таблица 1).

Таблица 1 - Частота выбора варианта ответа «да, хватает» респондентами различных возрастных групп

\begin{tabular}{|c|c|}
\hline Возраст & Доля, \% \\
\hline $15-17$ лет & 47,0 \\
\hline $18-21$ год & 38,0 \\
\hline $22-25$ лет & 33,5 \\
\hline $26-30$ лет & 20,5 \\
\hline
\end{tabular}

Студенческая молодежь Оренбуржья обладает бо́льшим количеством свободного времени, только 14,5 \% респондентов отмечают, что им не хватает времени для занятия любимым делом [6, c. 381]. «Семейный статус также влияет на выбор вариантов ответа на данный вопрос - только 18,0 \% респондентов, состоящих в браке, имеющих детей, утверждают, что им достаточно времени для досуга» [7, с. 21-22]. Таким образом, старшеклассники и студенты располагают большим количеством свободного времени и могут посвятить его досуговой деятельности, в то время как молодежь старшего возраста значительную его часть тратит на бытовые хлопоты и семейные заботы.

Следующий блок вопросов выявляет наиболее востребованные формы досуга молодежи, основные фракторы, влияющие на их выбор. Одной из главных причин повышения интереса индивида к сфере досуга, как известно, стала научно-техническая революция - механизация, затем автоматизация и роботизация производства, интенсификация труда, т. е. технологический прогресс, реально сокративший рабочее время и увеличивший внерабочее, которое необходимо было «занять чем-то интересным». Это привело к стремительному расширению сферы услуг, формированию инновационных, технологически сложных форм досуга.

Вариации в данном сегменте выглядят следующим образом: более половины опрошенных молодых астраханцев в свободное время «обычно сидят в Интернете» $(55,9 \%)$, чуть меньше половины - смотрят телевизор $(44,8)$, треть - слушают музыку $(34,5 \%)$. Вместе с тем самыми интересными видами организации досуга для молодежи являются «путешествие по разным городам и странам» $(20,2 \%)$, «посещение выставок, музеев, театров» $(17,5)$, «кино» $(15,2)$, «посещение концертов, фестивалей, массовых праздников» (15,2 \%). При этом в повседневной жизни лишь небольшая часть молодежи реализует свой интерес: ходят на концерты, фестивали, массовые праздники 7,2 \% респондентов; выставки, музеи, театры посещают и того меньше - 4,0; а путешествуют только 1,9 \% [8, с. 26].

В аутсайдерах оказались такие виды досуга, как спорт и физическая культура (15,8 \%); занятия в кружках художественной самодеятельности, клубах по интересам, секциях $(9,1)$; «выезд на природу» (в том числе охота, рыбалка) $(7,2)$; «посещение религиозных учреждений» $(3,7)$; волонтерство, общественная деятельность и благотворительность $(2,9$ \%) [9, с. 28]. Например, в Москве большая часть молодежи ориентирована на активный досуг. В свободное время они предпочитают заниматься спортом, гулять или находиться на свежем воздухе $(59,3$ \%). Ночной образ жизни, а именно посещение ночных увеселительных заведений, выбирают 13,7 \% респондентов. Десятая часть молодых москвичей посвящает свой досуг Интернету, 8,0 - саморазвитию, $9,0 \%$ опрошенных - домашним делам [10]. 
Таким образом, полученные данные свидетельствуют о том, что современная астраханская молодежь выбирает пассивные виды времяпрепровождения: Интернет, просмотр телепрограмм, прослушивание музыки, а молодежь мегаполиса предпочитает активные формы досуга. Причина этого, в частности, кроется в выборке респондентов: в Астраханской области опрашивали как жителей областного и районных центров, так и сельчан. Хотя «рыбалка и охота» - своеобразный маркер региона, но, видимо, этот вид досуга характерен для более «взрослого», «возрастного» населения. Объективной причиной, как уже говорилось, является научно-технический прогресс, который постоянно совершенствует наш объектный мир, наполняя его новыми гаджетами, совершенствуя старые. Одним из таких изобретений и стал Интернет. В современном информационном пространстве трудно представить человека, не пользующегося «благами» виртуальной сети, тем более представителя молодого поколения.

Далее стояла задача выявить, существует ли расхождение в восприятии молодежью терминов «хобби» и «досуг». Следует отметить, что для большей части молодых астраханцев (55,8 \%) в трактовке этих двух категорий есть различия: «хобби - это занятие, которое находит для себя человек в целях расслабления и получения положительных эмоций, он занимается им в свободное время или, как говорят, на досуге». Таким образом, понятие «хобби» вытекает из понятия «досуг» и означает конкретную деятельность, которой индивид занимается с определенным постоянством. Основная цель хобби - самореализация. Оно со временем может вырасти в основную деятельность, приносящую доход. У 38,4 \% опрошенных есть постоянное увлечение, т. е. хобби; 26,8 \% из них отличают его от досуга [11, с. 35].

Например, социологическое исследование, проведенное в Республике Бурятия, показало, что занятие любимым делом во всех возрастных группах молодежи не вошло в число ежедневных распространенных видов досуговой деятельности, нет хобби у 29,1 \% респондентов; из них 51,5 \% мужчин и 48,5 \% женщин. Из ответивших утвердительно на вопрос о наличии хобби $28,8 \%$ опрошенных занимаются им ежедневно, 27,2 \% - 1-2 раза в неделю. Основные названные виды хобби - паркур, пейнтбол, альпинизм, рыбалка, охота, домоводство и рукоделие. Территориальный фактор влияет на наличие хобби у участников опроса. Так, среди сельских жителей больше представителей молодого поколения, имеющих постоянное увлечение, $-47,6$ \%; в то время как среди горожан подобных людей всего 29,3 \%. Больше половины респондентов среди сельской молодежи $(60,6 \%)$ отметили, что хобби и досуг - разные по смыслу слова, среди городских жителей таких 51,0\% [12, с. 128].

Одним из интересных аспектов социологического анализа является блок, касающийся степени удовлетворенности молодежи организацией досуга. Стоит отметить, что большинство молодых людей, проживающих в Астраханской области, положительно оценивают организацию досуга в их населенном пункте (абсолютно удовлетворены - 30,8 \%, скорее удовлетворены 46,5 \%). Среди городских жителей больше всего тех, кто выразил высокую степень удовлетворенности организацией досуга: абсолютно удовлетворены 44,0 \%, среди сельчан таких 17,5 \%. Респонденты в возрасте 22-25 лет выше представителей других возрастных категорий оценивают уровень организации их свободного времени. Не совсем довольны данной сферой 22,7 \% опрошенных (не удовлетворены - 7,7 \%, скорее не удовлетворены - 15,0 \%). По их мнению, на качество досуга современного молодого поколения оказывают влияние в первую очередь субъективные факторы, а именно - отсутствие новых идей, исходящих от самой молодежи (так считают 30,5 \% участников исследования) [13, с. 51-52].

Высока степень удовлетворенности респондентов организацией досуга в Мурманской области. Около половины опрошенных (46,5 \%) скорее удовлетворены и полностью удовлетворены услугами в области развлекательного досуга (кинотеатрами, дискотеками, клубами, кафе, ресторанами, барами и др.); 45,4 \% молодежи отметили, что они скорее удовлетворены массовыми праздниками, народными гуляниями и массово-зрелищными мероприятиями, чем не удовлетворены ими; 40,0 \% молодых людей скорее удовлетворены молодежными досуговыми мероприятиями и полностью удовлетворены ими. Менее всего представители молодого поколения довольны рекреационным досугом (только 35,3 \% оценили свою удовлетворенность в 4 и 5 баллов) [14, с. 342].

Причинами неудовлетворенности молодых горожан услугами в сфере досуга можно назвать следующие. Наиболее значимая - недостаточное количество и разнообразие услуг $(56,9 \%)$, на втором месте - отсутствие информации об услугах $(36,2)$ и их высокая стоимость $(36,2$ \%). Респонденты, проживающие в Мурманской области, второй по значимости причиной неудовлетворенности выделили низкое качество услуг. На последующих местах находятся отсутствие информации $(26,5 \%)$ и высокая стоимость $(20,5$ \%) [15, с. 343].

В Астраханской области помимо указанных причин молодежь отмечает, что в вопросах организации досуга не хватает поддержки со стороны органов местного самоуправления в решении организационных вопросов по улучшению рекреационной инфраструктуры. Такого мнения придерживаются 26,8 \% респондентов. 18,0 \% опрошенных считают, что специализированных мест для проведения досуга недостаточно. 
Результаты социологического исследования в Оренбургской области еще раз подтвердили наличие типовых проблем организации досуга: отсутствие свободного времени - 14,5 \%; финансовые затруднения - 47,3; отсутствие учреждений с организованной досуговой деятельностью (мест проведения досуга) - 25,5\% [16, с. 381].

Таким образом, сравнительный анализ результатов социологических опросов показал, что досуговые предпочтения современной молодежи, несмотря на региональные особенности, имеют общие закономерности. Среди них можно назвать следующие: во-первых, большей части молодежи, не обремененной семьей, хватает свободного времени для проведения досуга; вовторых, молодые люди предпочитают находиться дома за компьютером, общаясь во всевозможных социальных сетях, просматривая сайты, фильмы, читая книги; в-третьих, немалая часть молодежи занимается спортом; в-четвертых, на степень удовлетворенности сферой досуга влияют доступность, разнообразие и качество предоставляемых услуг.

Резюмируя изложенное, необходимо отметить, что повышение качества и доступности услуг муниципальных учреждений культуры является одним из приоритетных направлений политики как регионального правительства, так и органов местного самоуправления, а регулярные замеры удовлетворенности услугой позволяют своевременно принимать предупредительные меры.

\section{Ссылки и примечания:}

1. Маркс К. Социология : сборник. М., 2000. 432 с

2. Kaplan M. Leisure // Theory and Police. Vol. 4. L., 1985. 268 p.

3. Иконникова С.Н. Социология о молодежи (Проблемы воспитания духовного облика). Л., 1985. 32 с.

4. Дробинская Е.И. Свободное время и развитие личности. Л., 1983. 89 с.

5. Бабосова Е.С. Досуг как фрактор включенности молодежи в социокультурную деятельность // Социологический альманах. 2012. № 3. С. 336-344.

6. Боброва Г.В. Основные проблемы организации досуга студенческой молодежи на примере Оренбургского государственного университета // Психология и педагогика: методика и проблемы практического применения. 2011. № 23. С. 380-384.

7. Досуговые предпочтения молодежи Астраханской области : результаты социологического исследования. Астрахань, 2016. C. $21-22$

8. Там же. С. 26

9. Там же. С. 28

10. Согласно данным социологического исследования «Хобби и увлечения современной молодежи», разработанного и проведенного сотрудниками и студентами МСПИ в 2013 г. ( $n=480$ человек).

11. Досуговые предпочтения ... С. 35.

12. Жамсуева О.С. Досуг сельской молодежи на современном этапе развития общества // Вестник Бурятского государственного университета. 2013. № 14. С. 124-128.

13. Досуговые предпочтения ... С. 51-52.

14. Недосека Е.В. К проблеме организации досуга молодежи в Мурманской области // Вестник МГТУ. 2013. Т. 16, № 2. C. 342.

15. Там же. С. 343

16. Боброва Г.В. Указ. соч. С. 381

\section{References:}

Babosova, ES 2012, 'Leisure as a factor of youth involvement in social and cultural activities', Sotsiologicheskiy al'manakh, no. 3, pp. 336-344, (in Russian).

Bobrova, GV 2011, 'The main problems of leisure activities of students by a case study of Orenburg State University', Psikhologiya i pedagogika: metodika i problemy prakticheskogo primeneniya, no. 23, pp. 380-384, (in Russian).

Drobinskaya, El 1983, Free time and personal development, Leningrad, 89 p., (in Russian).

Ikonnikova, SN 1985, Sociology of youth (Problems of creating the spiritual image), Leningrad, 32 p., (in Russian).

Kaplan, M 1985, 'Leisure', Theory and Police, vol. 4, London, 268 p.

Leisure preferences of young people in Astrakhan region: sociological research results 2016, Astrakhan, pp. 21-22, 26, 28, 51-52, (in Russian).

Marx, K 2000, Sociology: a collection, Moscow, 432 p., (in Russian).

Nedoseka, EV 2013, 'Concerning the problem of leisure activities of young people in Murmansk region', Vestnik MGTU, vol. 16, no. 2, pp. 342, 343, (in Russian).

Zhamsueva, OS 2013, 'Leisure of the rural youth at the present stage of the society's development', Vestnik Buryatskogo gosudarstvennogo universiteta, no. 14, pp. 124-128, (in Russian). 